\title{
КЛІНІЧНІ ТА ІМУНОЛОГІЧНІ ПРОЯВИ ПОЄДНАНИХ БОРЕЛІОЗІВ У ПРАЦІВНИКІВ ЛІСОВИХ ГОСПОДАРСТВ ТЕРНОПІЛЬСЬКОЇ ОБЛАСТІ
}

Вступ. Вивчення клінічних та імунологічних проявів поєднаних бореліозів залишається актуальною проблемою сучасної інфректології.

Мета дослідження - вивчити клінічні та імунологічні прояви поєднаних бореліозів у працівників лісових господарств Тернопільської області.

Методи дослідження. Проведено клініко-лабораторне обстеження 106 лісівників Тернопільської області віком від 20 до 65 років; чоловіків було 95,3 \%, жінок - 4,7\%. Контрольну групу становили 25 донорів крові, які за віком і статтю відповідали розподілу обстежених хворих, в анамнезі не вказували на присмоктування кліщів. У сироватках крові лісівників визначали наявність специфрічних імуноглобулінів (Ig) класів М i G до збудників Лайм-бореліозу (ЛБ), використавши двоетапний метод діагностики (імуноферментний аналіз (ІФА) та імуноблот), застосувавши тест-системи компанії “Euroimmun AG" (Німеччина). Отримані результати інтерпретували відповідно до рекомендацій виробника. Специфрічні IgM ma IgG до B. miуyатоtoi (одного зі збудників кліщових поворотних гарячок) визначали у сироватці крові методом імуноблоту в лабораторії "IGeneX Inc." (Мілпітас, Каліфорнія, США). Концентрацію IgA, IgM, IgG ma IgE визначали методом ІФА з використанням наборів "ІФА-Бест". Рівень ендогенної інтоксикації оцінювали за сорбційною здатністю еритроцитів, яку визначали за методом А. А. Тогайбаєва (1981).

Результати й обговорення. Серед лісівників Тернопільської області, за двома методами діагностики (ІФА та імуноблот), виявлено 49,1 \% серопозитивних осіб до B. burgdorferi s. I., до B. burgdorferi s. I. i B. miyamotoi одночасно - 25,5%. У хворих на поєднані бореліози, зумовлені B. burgdorferi s. I. і B. miyamotoi, клінічна картина недуги суттєво відрізнялася від клінічної картини Лайм-бореліозу, спричиненого лише B. burgdorferi s. l.: достовірно частіше відзначали гарячку, біль голови, втому/загальну слабість, міалгії, лімфаденопатію, послаблення концентрації уваги, свербіж шкіри, в тому числі й віддалено від місць присмоктування кліщів (p<0,05). У лісівників, хворих на поєднані бореліози, відмічали суттєво вищі показники сироваткового IgE і сорбційної здатності еритроцитів, ніж в осіб, в яких ЛБ був зумовлений лише B. burgdorferi s. I.

Висновок. Доцільно хворих на ЛБ, в яких відзначають тривалу гарячку, виражений свербіж шкіри поза місцями присмоктування кліщів, обстежувати на наявність можливого інфрікування ще й В. miyamotoi.

КЛЮЧОВІ СЛОВА: Лайм-бореліоз; кліщові поворотні гарячки; лісівники; імуноглобуліни класу Е; сорбційна здатність еритроцитів.

ВСТУП. Борелії - грамнегативні анаеробні мікроорганізми, які належать до класу Spirochaetes, порядку Spirochaetales, родини Spirochaetaceae, роду Borrelia, відрізняються за біологічними і культуральними властивостями. Частина з них спричиняє захворювання в людей, зокрема Лайм-бореліоз (ЛБ) та кліщові поворотні гарячки (КПГ, англ. Tick-borne relapsing fever TBRF) [1].

Натепер під назвою “Лайм-бореліоз” об'єднані, згідно зі спільністю їх патогенезу та етіології, відомі раніше, але розрізнені синдроми ураження шкіри, серцево-судинної і нервової сис-

(с К. Б. Штокайло, М. І. Шкільна, О. Л. Івахів, І. М. Кліщ, Г. Г. Габор, 3. В. Смаглій, 2021. тем, опорно-рухового апарату, рідше - інших органів та систем [2].

Тернопільська область ендемічна щодо лБ. Про це свідчить виявлення осередків іксодових кліщових бореліозів у 57 населених пунктах 14 районів області та в м. Тернополі [3]. Згідно з даними ДУ “Тернопільський ОЦКПХ МОЗ України", зараженість відібраних із довкілля кліщів B. burgdorferi sensu lato (s. I.) становила 53,6 \%, B. miyamotoi - 5,4 \% [4]. Науковці Центру з вивчення Лайм-бореліозу та інших інфекцій, що передаються кліщами, який функціонує при Тернопільському національному медичному університеті імені І. Я. Горбачевського МОЗ України, ДНК В. burgdorferis. І. виявили в 19,2 \% іксодових 
кліщів, відібраних від людей, B. miyamotoi - в 1,7 \% особин [5].

Найпоширенішими збудниками КПГє Borrelia duttoni, B. hermsii, B. parkeri, B. turicatae, рідше недугу спричиняють $B$. crocidurae, B. hispanica. В останні роки причетною до КПГ вважають ще й B. miyamotoi [6]. За даними вчених ряду країн, здебільшого клінічними проявами поворотних гарячок, викликаних B. miyamotoi, є періодичне підвищення температури тіла з грипоподібними симптомами, такими, як артралгії, міалгії, біль голови, нудота і втома/загальна слабість, а також ураження центральної нервової системи, зокрема менінгоенцефраліт [7, 8].

Однак є лише поодинокі повідомлення про виявлення борелій цього геновиду у хворих жителів України, в тому числі й працівників лісових господарств [9].

Особливістю патогенезу лБ є відносно повільна і слабка імунна відповідь, під час якої утворюються переважно специфрічні IgM та IgG до B. burgdorferi s.l., а також синтезується невелика кількість антитіл інших класів, зокрема IgA й IgE [10]. Даних про імунопатогенез недуги, спричиненої B. miyamotoi, натепер недостатньо [11].

Зазначене вище диктує необхідність поглибленого вивчення клінічних та імунологічних проявів поєднаних бореліозів у жителів України, зокрема Тернопільщини, в людей найбільш вразливих щодо кліщових індрекцій профресій працівників лісових господарств.

Мета дослідження - вивчити клінічні та імунологічні прояви поєднаних бореліозів у працівників лісових господарств Тернопільської області.

МЕТОДИ ДОСЛІДЖЕННЯ. У динаміці проведено поглиблене комплексне клініко-лабораторне обстеження 106 працівників 3 лісових (Бучацького, Кременецького, Тернопільського) і Бережанського лісомисливського господарств Тернопільської області. Пацієнти були віком від 20 до 65 років; чоловіків - 101 (95,3 \%), жінок 5 (4,7\%). Усі мали скарги, притаманні хворим на лБ. Контрольну групу становили 25 донорів крові, які за віком і статтю суттєво не відрізнялись від обстежених осіб, в анамнезі не вказували на присмоктування кліщів.

Працівники лісових господарств дали відповіді на запитання уніфрікованої анкети-опитувальника, яку розробили науковці Тернопільського національного медичного університету імені І. Я. Горбачевського МОЗ України разом із колегами з Державної вищої школи імені Папи Римського Іоанна Павла II (Бяла Подляска, Польща). У ній вони, зокрема, деталізували анамнестичні дані про наявність і кількість нападів кліщів.
Ця робота є фррагментом комплексних науково-дослідних робіт кафедри інфрекційних хвороб з епідеміологією, шкірними та венеричними хворобами Тернопільського національного медичного університету імені І. Я. Горбачевського МОЗ України "Вивчення епідеміології, патогенезу і клініки Лайм-бореліозу в ендемічних регіонах України, в тому числі в Тернопільській області, та вдосконалення його діагностики, терапії, реабілітаційних заходів і профрілактики" (№ державної реєстрації 0118U000357) та "Моно- і змішані інфекції, що передаються кліщами, вдосконалення лікувально-діагностичних технологій і заходів біобезпеки" (№ державної реєстрації 0120U104348), які фрінансуються за кошти МОЗ України.

У сироватках крові всіх обстежених лісівників визначали наявність специфічних $\lg M$ та $\lg G$ до збудників ЛБ. Дослідження проводили у 2 етапи. На першому етапі методом ELISA виявляли специфрічні імуноглобуліни зазначених вище класів до комплексу B. burgdorferi s. I., застосувавши тест-системи компанії "Euroimmun AG" (Німеччина). На другому етапі сироватки крові 3 позитивними і проміжними результатами першого етапу досліджували методом імуноблоту 3 використанням тест-системи EUROLINE-WB: Anti-Borrelia WB (IgM), Anti-Borrelia WB (IgG). 3a допомогою цього методу визначали специфрічні імуноглобуліни зазначених вище класів не лише до окремих геновидів борелій комплексу B. burgdorferi s. I., а й до низки антигенів збудників. Це дало змогу відкинути хибнопозитивні результати першого етапу дослідження. Отримані дані аналізували відповідно до рекомендацій виробника тест-систем.

У сироватках крові всіх обстежених визначали також наявність специфрічних IgM та IgG до B. miyamotoi. Дослідження проводили методом лінійного імуноблоту. В наборах цього різновиду імуноблоту на тестові стрип-мембрани у певному лінійному порядку нанесені лише високоспецифічні антигени (нативні, синтетичні або рекомбінантні) B. miyamotoi: GlpQ (периплазматичний ензим гліцерофросфродіефрірдестерази) [12], ВірА (імуногенний протеїн А) [13, 14], fHbp (поверхневий ліпопротеїн) [15] і FlaB (фрлагелін B) [12]. Застосування лінійного блоту дозволило відкинути хибнопозитивні результати і перехресні реакції виявлення специфічних антитіл до B. miyamotoi та B. burgdorferi s. I. Ці дослідження проводили науковці лабораторії "IGeneX Inc." (Мілпітас, Каліфорнія, США).

3 показників гуморального імунітету досліджували фрункціональну активність В-лімфроцитів, яку оцінювали за концентрацією сироваткових імуноглобулінів класів A, M, G та Е. Концент- 
рацію цих імуноглобулінів визначали методом імуносрерментного аналізу (ІФА) з використанням наборів: "Ig A - загальний - ІФА-БЕСТ", "Ig М загальний - ІФА-БЕСТ", "Ig G - загальний - ІФАБЕСТ", "Ig E - загальний - ІФА-БЕСТ". Для опрацювання отриманих результатів застосовували сервісну програму "РеалБест діагностика" (ЗАТ "Вектор-Бест").

Рівень ендогенної інтоксикації оцінювали за сорбційною здатністю еритроцитів (СЗЕ), яку визначали за методом А. А. Тогайбаєва (1981) [16]. Цей метод ґрунтується на здатності мембран еритроцитів адсорбувати барвник 0,025 \% метиленовий синій на ізотонічному розчині натрію хлориду.

Статистичне опрацювання отриманих результатів проводили за допомогою комп'ютерних програм Microsoft Office Excel i STATISTICA.

РЕЗУЛЬТАТИЙ ОБГОВОРЕННЯ. ПрИ ДОСЛідженні сироваток крові 106 лісівників скринінговим методом ІФА, а на другому етапі - методом імуноблоту позитивні результати щодо наявності специфрічних IgM та IgG до B. burgdorferi s. I. окремо іB. burgdorferis. I. одночасно $B$. miyamotoi отримали в 52 (49,1 \%) осіб. Зокрема, у 25 осіб (23,6 \% зі 106 обстежених) виявлено імуноглобуліни зазначених вище класів лише до B. burgdorferi s. I., у 27 (25,5\%) - одночасно до B. burgdorferi s. I. i B. miyamotoi.

За даними наукової літератури, у країнах Європи відсоток позитивних результатів виявлення антитіл до B. burgdorferi s. I. у сироватках крові лісівників коливається в досить широких межах - від 7,5 \% в Італії, 12,8 \% у Словакії до $30,0 \%$ у Німеччині [17]. Отримані нами результати виявлення протиборелійних антитіл у працівників лісових господарств Тернопільщини дещо вищі, що, мабуть, зумовлено більшою кількістю лісів, які є ареалом розповсюдження кліщів, і рідшим застосуванням лісівниками засобів індивідуального захисту (за даними анкетування).

Для вивчення клінічних та імунологічних особливостей поєднаних бореліозів у працівників лісових господарств Тернопільщини сорормували 2 групи пацієнтів. До 1-ї групи ввійшли 25 осіб 3 наявними сироватковими антитілами лише до B. burgdorferi s. І., до 2-ї - 27 пацієнтів з антитілами як до B. burgdorferi s. I., так і до B. miyamotoi, виявленими одночасно. Таким чином, поглиблено обстежено 52 лісівники.

3 опитаних 52 працівників лісових господарств напади кліщів в анамнезі відзначили 36 $(69,2$ \%) осіб, не пам'ятали їх - 16 (30,8 \%). На присмоктування кліщів один раз вказали 11 (30,6 \%) лісівників із 36 обстежених, два рази -
9 (25,0 \%), три рази і більше - 16 (44,4 \%); дані по групах наведено на рисунку.

Варто зазначити, що серед лісівників кожної з обстежених груп осіб, які в анамнезі мали 1 i 3 напади кліщів та більше, було майже однаково ( $>0,05)$. Водночас лісівників, які зазнавали нападів кліщів, було суттєво більше в 1-й групі, ніж у 2-й. Отже, 2 напади кліщів частіше відмічали хворі працівники лісових господарств, у сироватках яких виявляли специфічні антитіла лише до B. burgdorferis. I., порівняно 3 лісівниками з поєднаними бореліозами.

У подальшому з'ясовували клінічні прояви хвороби в обстежених пацієнтів. Встановлено, що у лісівників усіх груп найчастішими скаргами були артралгії, міалгії, припухлість суглобів, втома/загальна слабість, послаблення концентрації уваги і свербіж шкіри. Зниження зору, оніміння та відчуття слабкості в кінцівках, порушення сну, нудоту пацієнти відмічали значно рідше, причому однаково часто в усіх групах (табл. 1).

При ретельному аналізі частоти наявності різних скарг у пацієнтів кожної групи зокрема встановлено, що працівники лісу 1-ї групи, в яких виявляли лише сироваткові антитіла до B. burgdorferi s. I., здебільшого відзначали біль у суглобах та їх припухлість, а також послаблення концентрації уваги і свербіж, однаково часто в місці присмоктування кліща і поза його межами ( $>>0,05)$. Водночас лісівники, в яких знайдено сироваткові антитіла одночасно до B. burgdorferi s. I. i B. miyamotoi, переважно скаржилися на артралгії, припухлість суглобів, гарячку, біль голови, лімфаденопатію, підвищену втомлюваність/загальну слабість і свербіж, частіше поза місцем присмоктування кліща, однак достовірної різниці в частоті виявлення цих ознак не виявлено (див. табл. 1).

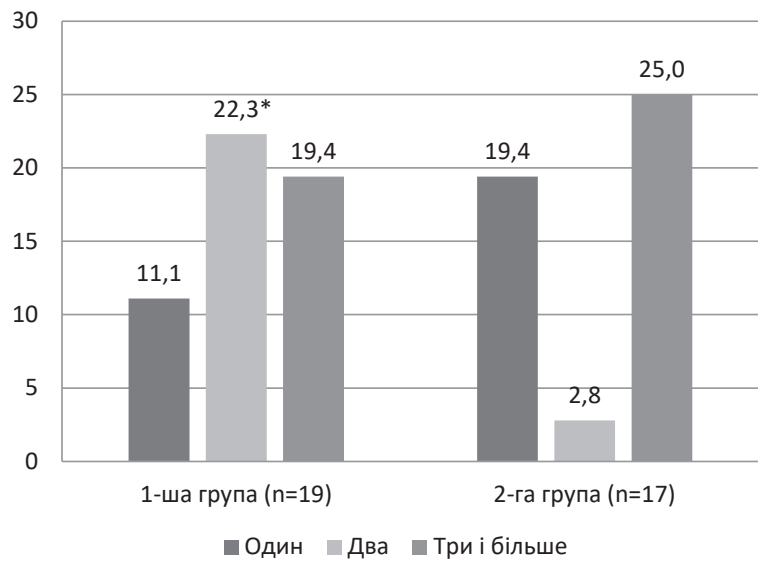

Рис. Кількість нападів кліщів, яких зазнали обстежені працівники лісових господарств Тернопільщини $(\mathrm{n}=36), \%$.

Примітка. * - достовірність різниці між групами $(p<0,05)$. 
Таблиця 1 - Частота клінічних проявів недуги в різних групах хворих працівників лісових господарств Тернопільської області $(n=52)$

\begin{tabular}{|l|c|c|c|c||}
\hline \multirow{2}{*}{ Ознака } & \multicolumn{4}{c|}{ Група хворих } \\
\cline { 2 - 5 } & \multicolumn{2}{|c|}{ 1-ша (n=25) } & \multicolumn{2}{c||}{ 2-га (n=27) } \\
\cline { 2 - 5 } & абс. число & $\%$ & абс. 4исло & $44,4^{*}$ \\
\hline Гарячка & 2 & 8,0 & 12 & $29,6^{*}$ \\
\hline Біль голови & 2 & 8,0 & 8 & $62,9^{*}$ \\
\hline Артралгії & 8 & 32,0 & 17 & $33,3^{*}$ \\
\hline Припухлість суглобів & 5 & 20,0 & 9 & $29,6^{*}$ \\
\hline Лімсаденопатія & 2 & 8,0 & 8 & $33,3^{*}$ \\
\hline Міалгії & 4 & 16,0 & 9 & $37,0^{*}$ \\
\hline Втома/загальна слабість & 4 & 16,0 & 10 & $29,6^{*}$ \\
\hline Послаблення концентрації уваги & 3 & 12,0 & 8 & 11,1 \\
\hline Кардіалгії, неприємні відчуття в ділянці \\
серця, порушення серцевого ритму
\end{tabular}

Примітка. * - різниця достовірна між групами $(p<0,05)$.

Встановлювали також, на що частіше скаржились хворі лісівники різних груп. 3'ясовано, що пацієнти 2-ї групи, в яких діагностовано ЛБ і були наявні ще й антитіла до B. miyamotoi, достовірно частіше скаржилися на гарячку порівняно з особами 1-ї групи - 44,4 проти 8,0 \%, біль голови - 29,6 проти 8,0 \%, втому/загальну слабість - 37,0 проти 16,0 \%, міалгії - 33,3 проти $16,0 \%$, а також відзначали збільшення лімфратичних вузлів, послаблення концентрації уваги, свербіж шкіри, в тому числі й віддалено від місць присмоктування кліщів $(p<0,05)$. Щодо артралгії і припухлості суглобів в осіб, в яких одночасно знайдено сироваткові антитіла до B. burgdorferi s. I. і B. miyamotoi, то, порівняно з хворими 1-ї групи, відзначено лише тенденцію до частішого виявлення цих скарг.

Таким чином, у хворих лісівників, у яких наявні сироваткові антитіла одночасно до B. burgdorferi s. I. та B. miyamotoi, цілу низку скарг відзначали значно частіше, ніж в осіб з ЛБ, в яких були лише антитіла до B. burgdorferi s. I. Мабуть,
B. miyamotoi, завдяки своїм фракторам агресії, чинить додатковий патологічний вплив на організм хворого, що й проявляється відповідною клінічною картиною недуги.

При аналізі показників гуморального імунітету в обстежених хворих виявлено певні зміни (табл. 2). Так, концентрація IgA та IgM у сироватках крові лісівників обох груп була суттєво вищою, ніж у контрольній групі $(p<0,05)$, проте не відрізнялася між групами обстежених пацієнтів. Вміст сироваткового IgG у хворих 1-ї групи мав лише тенденцію до зростання щодо показника в контрольній групі, а у пацієнтів з поєднаними бореліозами був суттєво більшим.

Наявність скарг в обстежених пацієнтів на наявність свербежу шкіри не лише в місцях присмоктування кліщів, але й поза ними, спонукала нас до визначення вмісту сироваткового $\operatorname{lgE}$, який є маркером алергії.

Встановлено, що концентрація IgЕ у пацієнтів 1-ї групи 3 наявними антитілами лише до B. burgdorferi s. I., мала тенденцію до підвищен-

Таблиця 2 - Показники гуморального імунітету та ендогенної інтоксикації в різних групах

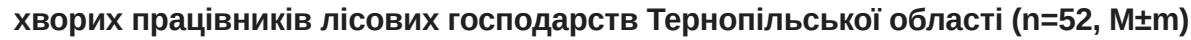

\begin{tabular}{|c|c|c|c|}
\hline \multirow{2}{*}{ Показник } & \multicolumn{3}{|c|}{ Група хворих } \\
\hline & контрольна $(\mathrm{n}=25)$ & 1-ша $(n=25)$ & 2-га $(n=27)$ \\
\hline $\lg \mathrm{A}$, г/л & $1,83 \pm 0,09$ & $6,58 \pm 0,75^{\star}$ & $6,56 \pm 0,76^{*}$ \\
\hline $\operatorname{lgM}, г / л$ & $1,46 \pm 0,08$ & $3,88 \pm 0,92^{*}$ & $3,37 \pm 0,26^{*}$ \\
\hline $\operatorname{lgG}$, г/л & $10,30 \pm 0,37$ & $18,03 \pm 0,57$ & $23,79 \pm 0,99 *$ \\
\hline $\lg \mathrm{E}$, од./мЛ & $75,00 \pm 5,00$ & $105,71 \pm 3,80$ & $216,26 \pm 10,89^{\star \star \star \star}$ \\
\hline C3E, \% & $27,25 \pm 1,22$ & $33,61 \pm 1,60$ & $79,75 \pm 1,29^{\star, \star \star}$ \\
\hline
\end{tabular}

Примітка. * - різниця достовірна щодо контрольної групи (р<0,05); ** - різниця достовірна між 1-ю і 2-ю групами $(p<0,05)$. 
ня щодо показника в контрольній групі. Водночас у хворих на поєднані кліщові бореліози (В. burgdorferi s.I. та B. miyamotoi) рівень IgE був суттєво більшим як щодо контролю, так і стосовно осіб інших груп (див. табл. 2).

Окрім того, у лісівників усіх груп визначали рівень ендогенної інтоксикації за показником СЗЕ. Так, лише у пацієнтів, у яких одночасно виявляли сироваткові антитіла як до B. burgdorferi s. I., так і до B. miyamotoi, рівень ендогенної інтоксикації був найвищим і суттєво відрізнявся від показника як у контрольній, так і в 1-й групах відповідно, $(79,75 \pm 1,29) \%$ проти $(27,25 \pm 1,22)$ і $(33,61+1,60) \%(p<0,05)$.

У хворих лісівників з поєднаною кліщовою інфекцією, мабуть, B. miyamotoi чинить додатковий до B. burgdorferi s. I. алергізуючий і токсичний вплив на організм пацієнта, тому в них суттєво вищі показники сироваткового IgE та СЗЕ, ніж в осіб, в яких ЛБ зумовлений лише B. burgdorferi s. I.

ВИСНОВКИ. 1. Серед лісівників Тернопільської області, за двома методами діагностики (імуноферментний аналіз та імуноблот), виявлено високий відсоток серопозитивних осіб до B. burgdorferi s. I. $-49,1 \%$, до B. burgdorferi s. I. i B. miyamotoi одночасно - 25,5\%.

\section{СПИСОК ЛІТЕРАТУРИ}

1. Trevisan G. Borreliae part 1: Borrelia Lyme group and Echidna-reptile group / G. Trevisan, M. Cinco, S. Trevisini [et al.] // Biology. - 2021. - 10 (10). - P. 1036. Access mode : https://doi.org/10.3390/biology 10101036

2. Андрейчин М. А. Лайм-бореліоз. Діагностичні критерії, лікування і профрілактика : метод. рек. / М. А. Андрейчин, В. С. Копча, М. І. Шкільна. - Тернопіль : ТДМУ, 2019. - 52 с.

3. Шкільна М. І. Лайм-бореліоз у працівників лісових господарств Тернопільської області / М. І. Шкільна // Інфекційні хвороби. -2016. - № 1 (83). - С. 36-40.

4. Зараженість кліщів у лісових біотопах Тернопільської області / В. О. Паничев, М. А. Андрейчин, Ю. А. Кравчук [та ін.] // Інорекційні хвороби. - 2021. № 2. - C. 44-52.

5. Шкільна М. І. Зараженість кліщів, відібраних від людей в Україні, збудниками деяких бактеріозів / М. І. Шкільна, М. А. Андрейчин, С. С. Подобівський // Буковин. мед. вісн. - 2020. - 24, № 1 (93). - С. 195-201.

6. Kubiak K. Borrelia miyamotoi - an emerging human tick-borne pathogen in Europe / K. Kubiak, M. Szczotko, M. Dmitryjuk // Microorganisms. - 2021. 9 (1). - P. 154. - Access mode : https://doi.org/10.3390/ microorganisms9010154

7. Borrelia miyamotoi disease: Neither Lyme disease nor relapsing fever / S. R. Telford, H. K. Goethert, P. J. Molloy [et al.] // Clin. Lab. Med. - 2015. - 35. -
2. У хворих на поєднані бореліози, зумовлені B. burgdorferi s. I. і B. miyamotoi, клінічна картина недуги суттєво відрізнялася від клінічної картини Лайм-бореліозу, спричиненого лише B. burgdorferi s. I.: достовірно частіше відзначали гарячку, біль голови, втому/загальну слабість, міалгії, а також лімсаденопатію, послаблення концентрації уваги, свербіж шкіри, в тому числі й віддалено від місць присмоктування кліщів $(p<0,05)$. Відзначено ще й тенденцію до частішого виявлення в таких пацієнтів артралгії і припухлості суглобів.

3. У лісівників, хворих на поєднані бореліози, відзначено суттєво вищі показники сироваткового IgE і сорбційної здатності еритроцитів, ніж в осіб, в яких Лайм-бореліоз був зумовлений лише B. burgdorferi S. I., що пояснює частіше виникнення в них свербежу шкіри і проявів інтоксикаційного синдрому.

4. Доцільно хворих на Лайм-бореліоз, в яких відзначають тривалу гарячку, виражений свербіж шкіри поза місцями присмоктування кліщів, обстежувати на наявність можливого інсрікування ще й B. miyamotoi.

Перспективи подальших досліджень передбачають вивчення імунологічних змін у пацієнтів з ураженням шкіри (морфеа та кропив'янка) при безеритемній формі Лайм-бореліозу.

P. 867-882. - Access mode : https://doi.org/10.1016/j. cll.2015.08.002

8. Relapsing fever Borrelia in California: A pilot serological study / M. J. Middelveen, J. S. Shah, M. C. Fesler, R. B. Stricker // Int. J. Gen. Med. - 2018. 11. -P. 373-382. -Access mode : https://doi.org/10.2147/ IJGM.S176493

9. Шкільна М. І. Клініко-епідеміологічні та імунологічні аспекти Лайм-бореліозу, вдосконалення діагностики і терапії : дис. ... доктора мед. наук : 14.01.13 / Шкільна Марія Іванівна. - Тернопіль, 2021. - 327 с.

10. Anderson C. The Brilliance of Borrelia: Mechanisms of host immune evasion by Lyme disease-causing spirochetes / C. Anderson, C. Brissette A. // Pathogens (Basel, Switzerland). - 2021. - 10 (3). - 281. - Access mode : https://doi.org/10.3390/pathogens10030281

11. Borrelia miyamotoi: a widespread tick-borne relapsing fever spirochete / A. Wagemakers, P. J. Staarink, H. Sprong, J. W. Hovius // Trends Parasitol. - 2015. 31 (6). - P. 260-269. DOI: 10.1016/j.pt.2015.03.008

12. Shah J. S. Species specific antigen sequences for tick-borne relapsing fever (TBRF) and methods of use / J. S. Shah, S. Liu. - U.S. Patent Application No.15/916,717. 9 March 2018.

13. A novel surface antigen of relapsing fever spirochetes can discriminate between relapsing fever and Lyme Borreliosis / J. E. Lopez, M. E. Schrumpf, 
V. Nagarajan [et al.] // Clin. Vaccine Immunol. - 2010. 17, No. 4. - P. 564-571. - Access mode : https://doi. org/10.1128/CVI.00518-09

14. Sequence analysis and serological responses against Borrelia turicatae BipA, a putative speciesspecific antigen / J. E. Lopez, H. K. Wilder, W. Boyle [et al.] // PLoS Negl. Trop. Dis. -2013. - 7, No. 9. -Access mode : https://doi.org/10.1371/journal.pntd.0002454

15. Immune evasion of Borrelia miyamotoi: CbiA, a novel outer surface protein exhibiting complement binding and inactivating properties / F. Röttgerding, A. Wage- makers, J. Koetsveld [et al.] // Sci. Rep. - 2017. - 7, No. 303. - Access mode : https://doi.org/10.1038/ s41598-017-00412-4

16. Метод определения эндогенной интоксикации / А. А. Тогайбаев, А. В. Кургузкин, И.В.Рикун [и др.] // Лаб. дело. - 1988. - № 9. - С. 22-24.

17. Lewandowska A. Epidemiology of Lyme disease among workers of forest inspectorates in Poland / A. Lewandowska // Annals of Agricultural and Environmental Medicine. - 2013. - 20 (2). - P. 329-331.

\section{REFERENCES}

1. Trevisan, G., Cinco, M., Trevisini, S., di Meo, N., Chersi, K., Ruscio, M., Forgione, P., \& Bonin, S. (2021). Borreliae part 1: Borrelia Lyme Group and Echidna-reptile group, Biology, 10 (10), 1036. Retrieved from: https://doi. org/10.3390/biology10101036

2. Andreichyn, M.A., Kopcha, V.S., \& Shkilna, M.I. (2019). Laim-borelioz. Diahnostychni kryterii, likuvannia i profilaktyka: metod. Rekomendatsii [Lyme borreliosis. Diagnostic criteria, treatment and prevention: Guiidelines]. Ternopil: TDMU [in Ukrainian].

3. Shkilna, M. (2016). Laim-borelioz u pratsivnykiv lisovykh hospodarstv Ternopilskoi oblasti [Lyme-borreliosis in forestry workers of Ternopil region]. Infektsiini khvoroby - Infectious Diseases, (1). DOI: 10.11603/16812727.2016.1.5957 [in Ukrainian].

4. Panychev, V., Andreichyn, M., Kravchuk, Yu., Dautov, A., \& Dubrovska, A. (2021). Zarazhenist klishchiv u lisovykh biotopakh Ternopilskoi oblasti [Tick infection in forest biotopes of Ternopil region]. Infektsiini khvoroby Infectious Diseases, (2), 44-52. DOI: 10.11603/16812727.2021.2.12164 [in Ukrainian].

5. Shkilna, M., Andreychyn, M., Podobivsky, S., Fedoniuk, L., Panychev, V., \& Ivakhiv, O. et al. (2020). Zarazhenist klishchiv, vidibranykh vid liudei v Ukraini, zbudnykamy deiakykh bakterioziv [Infection of ticks collected from humans in Ukraine, by causative agents of some bacteriosis]. Bukovynskyi medychnyi visnyk Bukovinian Medical Herald, 24 (1 (93), 195-201. DOI: 10.24061/2413-0737.xxiv.1.93.2020.26 [in Ukrainian].

6. Kubiak, K., Szczotko, M., \& Dmitryjuk, M. (2021). Borrelia miyamotoi - an emerging human tick-borne pathogen in Europe. Microorganisms, 9 (1), 154. Retrieved from: https://doi.org/10.3390/microorganisms 9010154

7. Telford, S.R.,3rd, Goethert, H.K., Molloy, P.J., Berardi, V.P., Chowdri, H.R., Gugliotta, J.L., \& Lepore, T.J. (2015). Borrelia miyamotoi disease: Neither Lyme disease nor relapsing fever. Clinics in Laboratory Medicine, 35 (4), 867-882. - Retrieved from: https://doi.org/10.1016/j. cll.2015.08.002

8. Middelveen, M.J., Shah, J.S., Fesler, M.C., \& Stricker, R.B. (2018). Relapsing fever Borrelia in California: a pilot serological study. International Journal of General Medicine, 11, 373-382. Retrieved from: https://doi. org/10.2147/IJGM.S176493

9. Shkilna, M.I. (2021) Kliniko-epidemiolohichni ta imunolohichni aspekty Laim-boreliozu, vdoskonalennia diahnostyky i terapii [Clinical and epidemiological and immunological aspects of Lyme borreliosis, improvement of diagnosis and therapy]. Candidate's thesis. Ternopil [in Ukrainian].

10. Anderson, C., \& Brissette, C.A. (2021). The brilliance of Borrelia: Mechanisms of host immune evasion by Lyme disease-causing spirochetes. Pathogens (Basel, Switzerland), 10 (3), 281. Retrieved from: https:// doi.org/10.3390/pathogens10030281

11. Wagemakers, A., Staarink, P.J., Sprong, H., \& Hovius, J.W. (2015). Borrelia miyamotoi: A widespread tick-borne relapsing fever spirochete. Trends Parasitol., 31 (6), 260-269. Retrieved from: https:// doi.org/10.1016/j. pt.2015.03.008

12. Shah, J.S., \& Liu, S. (2018). Species specific antigen sequences for tick-borne relapsing fever (TBRF) and methods of use. U.S. PatentApplication No.15/916,717.

13. Lopez, J.E., Schrumpf, M.E., Nagarajan, V., Raffel, S.J., McCoy, B.N., \& Schwan, T.G. (2010). A novel surface antigen of relapsing fever spirochetes can discriminate between relapsing fever and Lyme borreliosis. Clinical and Vaccine Immunology: CVI, 17 (4), 564-571. Retrieved from: https://doi.org/10.1128/ CVI.00518-09

14. Lopez, J.E., Wilder, H.K., Boyle, W., Drumheller, L.B., Thornton, J.A., Willeford, B., Morgan, T.W., \& Varela-Stokes, A. (2013). Sequence analysis and serological responses against Borrelia turicatae BipA, a putative species-specific antigen. PLoS Neglected Tropical Diseases, 7 (9), e2454. Retrieved from: https://doi. org/10.1371/journal.pntd.0002454

15. Röttgerding, F., Wagemakers, A., Koetsveld, J., Fingerle, V., Kirschfink, M., Hovius, J.W., Zipfel, P.F., Wallich, R., \& Kraiczy, P. (2017). Immune evasion of Borrelia miyamotoi: CbiA, a novel outer surface protein exhibiting complement binding and inactivating properties. Scientific Reports, 7 (1), 303. Retrieved from: https:// doi.org/10.1038/s41598-017-00412-4

16. Togaybaev, A., Kurguzkin, A.V., \& Rikun, I.V. (1988) Metod opredeleniya endogennoy intoksikatsii [Method for determining endogenous intoxication]. Lab. Delo - Laboratory Business, 9, 22-24 [in Russian].

17. Lewandowska, A., Kruba, Z., \& Filip, R. (2013). Epidemiology of Lyme disease among workers of forest inspectorates in Poland. Ann. Agric Environ. Med., 20 (2), 329-331. 


\section{CLINICAL AND IMMUNOLOGICAL MANIFESTATIONS OF COMBINED BORELIOSIS IN FORESTRY WORKERS OF TERNOPIL REGION}

Summary

Introduction. The study of clinical and immunological manifestations of combined borreliosis remains an urgent problem of modern infectology.

The aim of the study - to analyze the clinical and immunological manifestations of combined borreliosis in forestry workers of Ternopil region.

Research Methods. A clinical and laboratory examination of 106 foresters was conducted; aged 20-65; men $95.3 \%$, women $-4.7 \%$. The control group consisted of 25 blood donors, which by age and sex corresponded to the distribution of the examined persons, without ticks bites in anamnesis. The presence of specific IgM and IgG to Lyme borreliosis pathogens was determined in the blood sera of foresters using a two-stage diagnostic method (ELISA and immune blotting) using test systems by Euroimmun AG assay (Germany). The obtained results were interpreted according to the manufacturer's recommendations. Specific antibodies of IgM and IgG to B. miyamotoi (one of the causative agents of tick-borne relapsing fever) were determined in the laboratory IGeneX Inc. (Milpitas, CA, USA) by immune blotting. The concentration of immunoglobulins $A, M, G$ and $E$ were determined by ELISA using ELISA-Best kits. The level of endogenous intoxication was assessed by the sorption capacity of erythrocytes (SCE), which was determined by A. A. Togaybayev method (1981).

Results and Discussion. Among foresters of Ternopil region, according to two stage diagnostic methods (ELISA and immune blotting), a percentage of seropositive individuals for B. burgdorferi s. I. $-49.1 \%$, to B. burgdorferi s. I. and B. miyamotoi simultaneously - $25.5 \%$. Fever, headache, fatigue/general weakness, myalgias, lymphadenopathy, itchy skin, including far from the place of the tick bite significantly were more common in patients with combined borreliosis caused by B. burgdorferi s. I. and B. miyamotoi, unlike Lyme borreliosis caused only by $B$. burgdorferi s. I. ( $p<0.05)$. Foresters with combined borreliosis had significantly higher rates of IgE serum levels and sorption capacity of erythrocytes than persons with $L B$, caused only by $B$. burgdorferi s. I.

Conclusion. Patients with $L B$, who have a prolonged fever, severe itching of the skin far from places of tick bites, it is advisable to examine for the presence of possible infection of $B$. miyamotoi.

KEY WORDS: Lyme borreliosis; tick-bites relapsing fever; foresters; IgE; sorption capacity of erythrocytes.

Отримано 15.09.21

Адреса для листування: К. Б. Штокайло, Тернопільський національний медичний університет імені І. Я. Горбачевського моз України, майдан Волі, 1, Тернопіль, 46001, Україна, e-mail: yavorska.kb@gmail.com. 